PART II. PHYSICAL ACTIVITY OF SOCIAL AND PROFESSIONAL GROUPS DZIAŁ II. AKTYWNOŚĆ FIZYCZNA GRUP SPOŁECZNYCH I ZAWODOWYCH

\title{
HEALTH PROBLEMS OF SENIORS: SELECTED DISEASES OF THE OLD AGE
}

\section{PROBLEMY ZDROWOTNE SENIORÓW NA PRZYKŁADZIE WYBRANYCH CHORÓB WIEKU STARSZEGO}

\author{
Katarzyna Sygit ${ }^{1(\mathrm{~A}, \mathrm{~B}, \mathrm{C}, \mathrm{D}, \mathrm{E}, \mathrm{F}, \mathrm{G})}$ \\ ${ }^{1}$ Faculty of Physical Education and Health Promotion, University of Szczecin, Szczecin, Poland
}

Authors' contribution Wkład autorów: A. Study design/planning zaplanowanie badań B. Data collection/entry zebranie danych C. Data analysis/statistics dane - analiza i statystyki D. Data interpretation interpretacja danych E. Preparation of manuscript przygotowanie artykułu F. Literature analysis/search wyszukiwanie i analiza literatury G. Funds collection zebranie funduszy

\section{Summary}

Since the mid-eighties, the Polish society has witnessed a steady increase in the 65+ population. This demographic trend calls for a change in the organisation of health services and healthcare for this segment of the society. Old age is a difficult period in human life, especially if one has not been prepared for it. Individuals experience a number of health restrictions, while the quality of life at that stage of life depends mostly on the accuracy of identifying health needs, their types and the quality of the available solutions. The following paper aims to present literature on the most common health problems amongst the elderly in Poland. Numerous scientific centres in Poland (and abroad) which work with seniors have confirmed that the health situation of this age group is highly unsatisfactory. Seniors often face problems which affect their functioning, independence and self-care. Impairment may be caused by geriatric disorders, which include cardiovascular diseases (the most common cause of death in Poland among persons aged 65+), cancer, diabetes, balance disorders, impaired mobility, falling down, dementia, depression, insomnia, incontinence, soiling, impaired vision and hearing, lower limb muscle cramps at night, and bedsores.

The rapid ageing of the society poses numerous challenges for healthcare organisers, educators and doctors with regard to educating, preventing and treating seniors in Poland.

Keywords: elderly, health problems, demographic situation

\section{Streszczenie}

W polskim społeczeństwie od połowy lat osiemdziesiątych systematycznie wzrasta liczba osób powyżej 65 roku życia. Te zmiany demograficzne wymuszają konieczność zmian w organizacji ochrony zdrowia i opieki nad tą grupą osób. Starość jest trudnym okresem w życiu człowieka, zwłaszcza jeśli nie został on do tego okresu przygotowany. Doświadcza w szczególności wielu ograniczeń zdrowotnych a jakość życia w tym okresie w znacznej mierze zależy od rodzajów i trafności rozpoznawania potrzeb zdrowotnych oraz jakości ich zaspokajania. Celem niniejszej pracy jest przedstawienie w świetle literatury przedmiotu najczestszych problemów zdrowotnych polskich seniorów. Liczne ośrodki naukowe w Polsce (również i zagranicą) zajmujące się sytuacja osób starszych i potwierdzają, iż sytuacja zdrowotna tej populacji jest wielce niezadowalająca. Osoby w wieku starszym często borykaja sie z problemami wpływajacymi na ich funkcjonowanie, samodzielność i samopielęgnowanie. Na stany powodujące upośledzenie funkcjonowania człowieka składają się wielkie zespoły geriatryczne, do których zalicza się: choroby układu krążenia (które są najczęstszą przyczyną zgonów w Polsce wśród osób po 65 roku życia), nowotwory, cukrzyca, zaburzenia równowagi, upośledzenie lokomocji, upadki, zespoły otępienne, depresję, bezsenność, nietrzymanie moczu i stolca, zaparcia, upośledzenie wzroku i słuchu, kurcze nocne mięśni kończyn dolnych, odleżyny. Przyspieszone starzenia się społeczeństwa stawia przed organizatorami ochrony zdrowia, szkolnictwa i lekarzami wiele wyzwań w zakresie edukacji, prewencji i leczenia populacji geriatrycznej w Polsce.

Słowa kluczowe: starość, problemy zdrowotne, sytuacja demograficzna 


\section{Introduction}

Since the mid-eighties, the Polish society has witnessed a steady increase in the $65+$ population [1]. This demographic trend calls for a change in the organization of health services and healthcare for this segment of the society. Scientific research and long-term demographic forecasts serve as a foundation for developing guidelines for new health policies that would meet seniors' needs $[1,2,3]$.

Social, educational and health adaptation, along with physical activity, increase the potential health of seniors and their appreciation for well-being and independence, as well as active participation in social life [4]. Innovative programmes play a significant role in maintaining the strength and physical fitness of seniors, while recovery programmes help cope with sight, hearing and mobility impairments before they lead to disability and dependency on others at a later stage in life [4,5].

Old age is a difficult period in human life, especially if one has not been prepared for it. Individuals experience a number of health and social restrictions, while the quality of life in this period depends largely on the adequately identified health and social needs, their types and the quality of solutions. Limited fitness, multiple diseases and pathological changes of the body, loneliness - all these lead to the deterioration of the old people's social situation and living conditions $[4,5,6,7,8]$.

Healthcare workers and social workers should pay particular attention to the so-called 'pre-old age' period, which is the time enabling the soon-to-be seniors to prepare for old age and still enjoy physical and intellectual fitness and independence [6].

\section{Aim of the work}

The following paper aims to present the available literature on the most common health problems amongst the elderly in Poland.

\section{Brief description of the status of knowledge}

\section{Aging and old age}

Although seemingly related, the concepts of 'old age', an important, final period of life, and 'aging' are defined in a different way [5].

The concepts of old age and ageing may be considered in two ways - as an individual or collective phenomenon which impacts a group of individuals in the society, country or region. As an individual phenomenon, old age is a biological stage that completes the cycle of human life [5,6,7]. On the other hand, according to Kirkwood, ageing is a process of progressive impairment of vital body functions and loss of adaptability to environmental changes with increasing probability of death. In general, an inevitable result of the ageing process is the state of 'being old'. Thus, ageing, as accepted in the literature under a psychogerontological definition, is a dynamic process, while old age is a static one[5].

According to the life cycle theory by D.J. Levinson, old age is one of the stages, which is not homogeneous and can be divided into subsequent periods. The life cycle theory describes the changes in the psyche and behaviours which take place in an individual at the successive stages of life. The first phase of life is the phase of learning, gaining experience (including childhood and youth). The next one is adulthood - a period of implementation of knowledge. Finally, the last phase - old age - is a phase of regression. These phases may start and finish at different times, and there are no rigid limits for the beginning and the end of particular phases of life cycles $[5,6]$.

The psychological concept of life cycle created by E. Erikson divides life into eight stages. The last step is late adulthood, which begins at the age of 60-65 [5,9,10].

Thus, ageing is a natural process which cannot be stopped or reversed. Every man goes through this process, but they do it differently [5,11,12].

Table 1. Division of old age by the World Health Organization (WHO)

\begin{tabular}{|c|c|c|}
\hline No. & Division of the old age & Age group \\
\hline 1. & 'young old' & $60-75$ years old \\
\hline 2. & 'old' & $75-90$ years old \\
\hline 3. & 'oldest old' & individuals over 90 \\
\hline
\end{tabular}

Source: Chodorowski Z. Geriatria: postępy w diagnostyce i terapii. Gdynia: Grafica; 2007 (in Polish). 
According to the United Nations, the age of 65 is considered the beginning of old age [5].

Old age is not only the number of years a person has lived. One may distinguish the so-called 'calendar age' (chronological) and 'biological age'. There may be a significant discrepancy between the chronological age and biological age which is caused by numerous factors $[10,12]$.

\section{Aging as a demographic process}

The numbers and structure of the 65+ population.

In the last 25 years, Poland has seen a slowdown in the demographic growth and significant changes in the age structure of its population. The ongoing ageing process of the Polish society results from a favourable phenomenon of longer life expectancy and a less desired low total fertility rate. Furthermore, these trends are also intensified by an increased emigration of young people [1,13].

Although Poland is still perceived as a demographically young country in Europe since the early 1990s the average age of a Polish citizen has increased by almost 7 years [14].

In 2013, the mean age for the entire Polish population was less than 39 years: 40 for women and almost 37 for men $[2,3,4]$.

Over the years 1989-2013, changes in the age structure of the population concerned mostly groups of children and adolescents (0-17 years), which faced the largest decrease, whilst the highest increase was visible in the so-called immobile production-age population (45-59/64 years), as well as the retirees (60/65+), including the groups aged 65 and more. The proportion of people aged 18-44 remained virtually unchanged in that period.

At the end of 2013, Poland had a population of 38.5 million, including approximately 5.7 million of $65+$ citizens. In the years 1989-2013, the number of seniors increased by almost 1.9 million. Its share in the total population grew by 4.7 percentage points, i.e. from $10 \%$ in 1989 to $14.7 \%$ in 2013 . For comparison, the proportion of children and adolescents decreased in that period by more than $10 \%$, from almost $30 \%$ to just over $18 \%$ [15].

Over the past 25 years, the subpopulation of seniors experienced the highest increase of individuals aged $80+$. Their share in the total Polish population doubled - from less than 2\% in 1989 to almost 4\% in 2013 (approx. from 753,000 to $1,483,000$ people). For comparison - the share of the slightly younger age group (65-79 years) increased in that period from $8 \%$ to less than $11 \%$ in the general population. This is a direct example of ageing of the Polish population, i.e. the result of increased life expectancy (increase in the 'oldest' age group). Additionally, the fertility rate in Poland is much lower, as the number of older people in the general population is growing while that of children and adolescents decreasing $[5,13,14]$.

Further, the process of demographic ageing is inconsistent as there are differences between the genders. The two subpopulations age at a different pace, which is the result of the so-called excessive male mortality. Women aged $65+$ represent $15.7 \%$ of the female sub-population, whereas men $65+$ account for only $10.4 \%$ of the male subpopulation [13].

Table 2. The average life expectancy of women by voivodships in Poland

\begin{tabular}{|c|c|c|}
\hline No. & $\begin{array}{c}\text { The average life expectancy } \\
\text { of women }\end{array}$ & Voivodship in Poland \\
\hline 1. & $78.5-79.5$ & Lubusz, Lower Silesian, Silesian, Lodz, \\
\hline 2. & $79.5-80.5$ & $\begin{array}{c}\text { Western-Pomeranian, Pomeranian, Warmian-Masurian, } \\
\text { Kuyavian-Pomeranian, Greater Poland, Opole, Lublin, }\end{array}$ \\
\hline 3. & $80.5-81.5$ & Lesser Poland, Subcarpathian, Swietokrzyskie, Masovian, Podlasie. \\
\hline
\end{tabular}

Source: GUS, Rocznik Demograficzny 2012, GUS. Warszawa; 2012 (in Polish).

Table 3. The average life expectancy of men by voivodships in Poland

\begin{tabular}{|c|c|c|}
\hline No. & $\begin{array}{c}\text { The average life expectancy } \\
\text { of men }\end{array}$ & Voivodship in Poland \\
\hline 1. & $68.0-69.5$ & Lodz, \\
\hline 2. & $69.5-71.0$ & Western-Pomeranian, Lubusz, Lower Silesian, Silesian, Lublin, Warmian-Masurian, \\
\hline 3. & $71.0-72.5$ & Opole, Greater Poland, Kuyavian-Pomeranian, Pomeranian, Masovian, Podlasie, \\
\hline 4. & $72.5-74.0$ & Leser Poland, Subcarpathian \\
\hline
\end{tabular}

Source: GUS, Rocznik Demograficzny 2012, GUS. Warszawa; 2012 (in Polish). 
Also, as researchers predict, the most advanced age group in the year 2030 will live in the south-western and southern region of Poland (the Sudetes and Upper Silesia), as well as north-western, central and north-eastern Poland $[5,15]$.

\section{Health of seniors}

Seniors often face problems which affect their functioning, independence and self-care. Impairment may be caused by geriatric disorders, which include cardiovascular diseases, cancer, diabetes, balance disorders, impaired locomotion, falling down, dementia, depression, insomnia, incontinence, soiling, impaired vision and hearing, night cramps of lower limbs, bedsores. Typically, the above-mentioned diseases and symptoms occur chronically and simultaneously, which complicates treatments. At the later stages, the disorders and symptoms often lead to disabilities and make seniors dependent on others $[4,6,9,16,17]$.

Also, the incidence of cardiovascular disease spikes with age. Unhealthy lifestyle is the main contributor to such diseases. Research has shown that senior men are more at risk than their female peers [17]. Heart diseases and cardiovascular system diseases are very dangerous for seniors, as they heavily strain the whole organism. Presently, cardiovascular diseases are among the leading causes of death. Chronic diseases of the cardiovascular system are a major health risk, but by maintaining appropriate guidelines, one can largely reduce symptoms and control the disease. One should also know which preventive examinations help in the early detection of the disease $[5,8]$.

One of the most common and frequent diseases in seniors is hypertension. The diagnosis of this problem is possible after observing persistent blood pressure over 140/90 $\mathrm{mmHg}$ (systolic/diastolic pressure), followed by a consultation with a doctor. The critical factor in treating and controlling the disease are daily measurements of pressure that help monitor the effectiveness of a drug therapy. Typically, this chronic disease requires an extended treatment, often until the end of the patient's life. Treating and consequently reducing blood pressure is extremely important as untreated hypertension may lead to, among others, heart attack, stroke or circulatory failure. It is worth mentioning that hypertension may not show symptoms for many years (sometimes they never appear), and patients may interpret fatigue and shortness of breath as an obvious consequence of age - not a symptom of a disease. For this reason, one should measure blood pressure, and if the result is high, the measurements must be done regularly to enable fast reaction if it maintains a high level $[6,9,12]$.

Besides, seniors are often diagnosed with cancer. This results from the development of many types of cancer, and its symptoms may be negligible or completely atypical. Another reason is the fact that seniors rarely remember about preventive check-ups which would allow early detection of cancer when it is often completely treatable. Another reason is the decline of natural immunity, which accompanies the ageing process and ultimately leads to increased susceptibility to diseases. Definitely, cancer may also result from years of neglecting health, following poor diet or smoking. One should know how to improve the chance of early detection of cancer in seniors, as well as reduce the risk of cancer at the old age. The key seems to be a healthy and active lifestyle, regardless of age, as well as necessary preventive check-ups [5,6].

\section{Diabetes in seniors}

Type 2 diabetes (non-insulin-dependent) is a chronic disease. It is a metabolic syndrome characterised by insulin resistance and insulin deficiency. At the initial stage of the disease, there is a qualitative irregularity in insulin secretion. The first phase of quick insulin secretion disappears, along with its pulsating secretion. It is believed that both defects reduce the sensitivity of tissues to insulin. At the later stage of the disease, the amount of secreted insulin is reduced $[5,18]$.

Diabetes is present on almost all continents and in all human populations. The incidence and prevalence, however, varies in different countries, and even among different ethnic groups. It has been observed that the prevalence of diabetes significantly increases in countries that experience rapid development rates. Then, lifestyles change dramatically, mainly with regard to diets, leisure time activities and preventive measures. Furthermore, approximately $20 \%$ of populations were aged $65+$ in many Western societies at the recent turn of centuries. One in five people in this age group has diabetes, and one in five is diagnosed with glucose tolerance. For these reasons, diabetes is going to be the primary health problem of the 21 century. Presently, in Poland, for every person with diabetes (diagnosed or not), there is one person with impaired glucose tolerance. In total, it gives about 1.6 million people with reduced carbohydrate processing. The World Health Organization's experts estimate that by 2020 , the number of people with diabetes worldwide will have exceeded 100 million people (by 2025, the diabetes incidence will increase even further). $85 \%$ of those persons will suffer from type 2 diabetes. This type of diabetes is often associated with obesity ( $80 \%$ of the patients are overweight to some extent) $[9,11]$. 
According to the American study NHANES II, the prevalence of diabetes and impaired glucose tolerance in patients aged $55-64$ years is $13.4 \%$ (diabetes) and 15.1\% (impaired glucose tolerance), while in the $65-74$ age group it is $18.7 \%$ and $22.8 \%$, respectively. As these results indicate, the prevalence of diabetes and impaired glucose tolerance in the $65+$ age group is as high as $41.5 \%$ in total. The development of this type of diabetes is a slow process. Patients often do not experience any clinical symptoms for many years. Vascular complications, however, develop unnoticed and lead to severe consequences. These are recognised primarily by specialised doctors, not GPs. Complications are the leading cause of morbidity and mortality in type 2 diabetes patients. Diabetologists emphasise that approximately $50 \%$ of cases are not diagnosed [5].

Further, the human body decreases insulin secretion in old age (65+), develops insulin resistance, and increases the growth of hyperglycaemic effect of other hormones. Numerous other factors are involved as well, such as increased body fat, decreased physical activity, abnormal renal function, increased activity of the sympathetic nervous system, diabetogenic drugs (e.g. methylxanthines, B-blockers, diuretics, steroids) [6,19].

When diabetes is diagnosed in an older patient, the doctor is obliged to thoroughly investigate the case to determine the current state of the patient's health and potential complications. They should also assess their everyday activity, mental performance, and familiarise the patient with social conditions. The doctor must also solicit the names of all the drugs taken by the patient. If the patient takes medicines which affect glucose tolerance, withdrawal or dose reduction of such medication should be considered. Preliminary clinical evaluation is necessary to select individual treatment goals.

Currently, diabetologists have five interdependent treatments available:

- diet

- physical activity

- oral antidiabetic drugs

- insulin

- health education [5].

\section{Senile dementia}

Senile dementia (also known as senility) is a disease associated with an impaired cognitive function. Usually, it affects people over 65 years old and more often occurs in women than in men. It is difficult to diagnose since it is often confused with other diseases. With age, older people tend to have more problems with memory and cognition, but dementia is a disease whose symptoms develop rapidly. Proper and timely treatment can significantly improve the quality of life of affected seniors [20,21].

The first symptom that could indicate senile dementia is memory impairment, which is often attributed to old age and therefore downplayed. The person with senile dementia can recall events that occurred many years earlier but cannot remember what they did the day before. Subsequently, the following symptoms may appear like memory loss, personality changes, mood swings, apathy and malaise [22].

The leading cause of senile dementia is brain damage, which is a symptom of many neurodegenerative diseases, ultimately leading to the degeneration of nerve tissue. One of the most common diseases leading to dementia is Alzheimer's disease, which causes the so-called Alzheimer's type dementia. Brain research conducted on people who died of Alzheimer's disease showed deposits which prevented connections between nerve cells. These cells died and formed blockades, which impaired transfer of information from one neuron to another. Another reason for the appearance of senile dementia is Pick's disease, which is characterised by similar disorders leading to the degeneration of the temporal and frontal lobes. There is also Parkinson's disease dementia, Lewy bodies dementia, Huntington's disease dementia and Creutzfeld-Jakob disease characterised by rapidly progressive dementia $[22,23,24]$.

Dementia cannot be prevented entirely as it is partially associated with ageing, but it can be slowed down $[25,26]$.

\section{Causes of deaths and mortality}

Aging is accompanied mostly by cardiovascular disease. Despite the drop in the percentage of deaths from cardiovascular disease among 65+ year-olds over the last quarter of a century, the condition is still responsible for over half of the deaths of seniors. In 2012, it caused 54\% of deaths, including ischemic heart disease (13\%) and atherosclerosis (11\%). In 2012, the incidence of deaths resulting from cardiovascular disease was nearly twice as high in seniors as among 65+ year-olds. Additionally, the share of seniors (aged 85+) in the total number of deaths caused by cardiovascular diseases amounted to over $80 \%[5,27]$. 
The second most common cause of death are tumours, including cancer.

In the last two decades, there was an increase in the proportion of seniors (by 7.5 percentage points) who died of tumours/cancer. In 1990, the proportion of deaths from tumours/cancer among seniors was approximately $16 \%$, whereas in 2012 it amounted to $23 \%$.

The data of the National Cancer Registry (KRN) indicate that nowadays every second case of cancer is detected in people aged 65+. The scale of this phenomenon may be illustrated by the number of cancers found among seniors only in one year. According to the latest data from KRN, in 2011 it was more than 73,000, which is an increase of almost $30 \%$ compared to the year 2000. The most common cancers in seniors include trachea cancer, bronchus and lungs cancer, and colorectal cancer $[13,28]$.

Other causes of death among seniors include diabetes, pneumonia, diseases of the genitourinary tract (including inflammation of the kidneys), stomach ulcers and duodenal ulcers, and chronic liver disease [5].

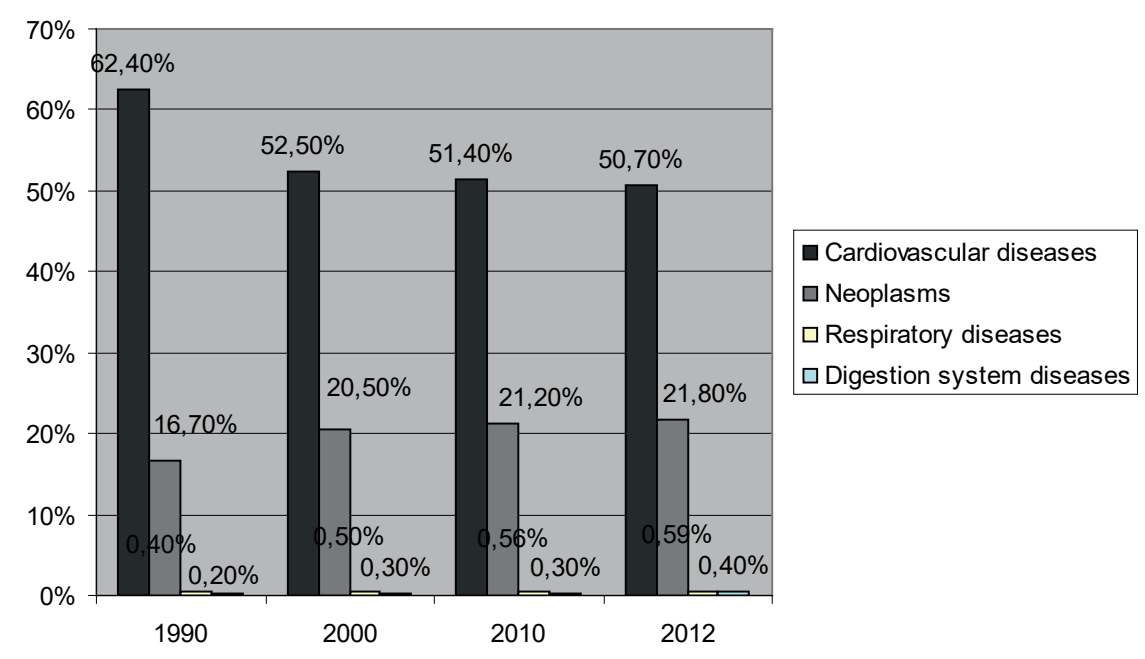

Figure 1. Selected causes of deaths in the 65+ age group (\%) in 1990, 2000, 2010, 2012

Source: Ślusarska B, Nowicki GJ, Bartoszek A, Wittwer S, Zboina B, Naylor K. Health problems of the elderly aged 65-75 years survised by a community nurse. Gerontol Pol 2016; 24(2): 17-25.

Furthermore, the structure of deaths classified by cause varies by gender. Among women, a frequent cause of death is cardiovascular disease, while men tend to die of cancer $[5,6,9]$.

\section{Discussion}

Intensified ageing of the Polish society poses numerous challenges for healthcare organisers, educators and doctors in terms of educating, preventing and treating seniors. Increased spending for the social security system and healthcare is foreseen [5]. It is necessary to introduce a social policy which would promote understanding of correlations between the current lifestyle and the quality of life at old age - both in terms of health, physical fitness and financial security. The ageing of the society has great consequences in terms of national finances. There is an increasing demand for retirement benefits and the need for health services specific to a particular old age. Therefore, legislation changes are necessary to define the framework for the future pension system and the social system $[5,6,28]$.

A good example of successful reforms is Finland. The position of the Finnish seniors on the labour market was strengthened by supporting their decision to stay professionally active or restore their activity. Another country is Japan, where the reforms had a positive impact on national finances.

Japan developed a positive image of senior workers and created an environment for cooperation between enterprises, the government and human resources.

Great Britain also serves as an example of an improved national budget. The social care system was reformed, and benefits reduced, while the retirement age was raised and higher pension got correlated to the extended period of professional activity.

The Polish population is not enthusiastic about such innovative reforms. Changing governing parties make it very challenging to keep a single direction of reforms $[5,6]$. Consequently, the increasing demographic ageing is a severe problem for the healthcare sector in Poland. 
With an increased frequency, seniors report a demand to use healthcare services, nursing treatment, medical consultations, and rehabilitation [12]. Poland lacks a model of Comprehensive Geriatric Assessment (KOG), based on a regular comprehensive study of the health of elderly patients which would take into account their family situation and living conditions. Only close cooperation between doctors, nurses and social workers could provide basic care for the elderly $[29,30]$.

\section{Conclusions}

The accelerated ageing population poses a severe challenge to the organisers of health, education, and doctors in the field of education, prevention and treatment of the Polish geriatric population. The deepening process of demographic ageing is therefore a serious problem for the Polish healthcare sector.

Accordingly, it is recommended that a system of institutions for seniors (social welfare homes, long-term care facilities, day-care centres) should be created that would be financed in a uniform manner and with an inclusion of public funds. Comprehensive support for families who care for seniors should be insured, enabling those who pursue their professional life reconcile their work and care of seniors. Finally, a system of community services for dependent seniors should be created allowing them to remain in the environment where they live.

\section{References:}

1. Błędowski P. Starzenie się jako problem społeczny. Perspektywy demograficznego starzenia się ludności Polski do roku 2035. In: Mossakowska M, Więcek A, Błędowski P., editors. Aspekty medyczne, psychologiczne, socjologiczne i ekonomiczne starzenia się ludzi w Polsce. Poznań: Termedia Wydawnictwo Medyczne; 2012. p. 18-36.

2. Instytut Pracy i Spraw Socjalnych, Raport na temat sytuacji osób starszych w Polsce. Warszawa; 2012 (in Polish).

3. GUS, Prognoza ludności na lata 2008-2035, GUS. Warszawa; 2009 (in Polish).

4. GUS, Rocznik Demograficzny 2012, GUS. Warszawa; 2012 (in Polish).

5. Kulik TB, Janiszewska M, Piróg E, Pacian A, Stefanowicz A, Żołnierczyk-Kieliszek D, et al. Sytuacja zdrowotna osób starszych w Polsce i innych krajach europejskich. Medycyna Ogólna i Nauki o Zdrowiu 2011; 17(2): 90-95.

6. Sygit K., editor. Problemy zdrowotne i społeczne seniorów. Szczecin: Wyd. Uniwersytet Szczeciński; 2010 (in Polish).

7. Szukalski P., editor. Przygotowanie do starości. Polacy wobec starzenia się. Warszawa: Instytut Spraw Publicznych; 2009 (in Polish).

8. Stenner P, McFarquhar T, Bowling A. Older people and 'active ageing': Subjective aspects of ageing actively. J Health Psycholo 2011; 16(3) 467-477. https://doi.org/10.1177/1359105310384298

9. Kostka T, Koziarska-Rościszewska M. Choroby wieku podeszłego. Warszawa: PZWL; 2009 (in Polish).

10. Galus K., editor. Geriatria. Wybrane zagadnienia. Wrocław: Urban\&Partner; 2007 (in Polish).

11. Marchewka A, Dąbrowski Z, Żołądź JA. Fizjologia starzenia się. Profilaktyka i rehabilitacja. Warszawa: PWN; 2012 (in Polish).

12. Rosenthal T, Naughton B, Williams M. Geriatria. Lublin: Wydawnictwo Czelej; 2009 (in Polish).

13. Podoski M. Polska krajem starców? Uwagi na temat starzenia się ludności Polski [Internet]. 2012 Jan [cited 2016 Dec 3]. Available from: http://www.deon.pl/czytelnia/czasopisma/przeglad-powszechny/art,1,polskakrajem-starcow-uwagi-na-temat starzenia-sie-ludnosci-polski.html.

14. Nowak-Far A. Methuselach Perplexus - polityka prawa wobec zmian demograficznych w Europie. In: Osiński J., editor. Współczesne problemy demograficzne. Rzeczywistość i mity. Ujęcie krajowe, regionalne i globalne. Warszawa: Oficyna Wydawnicza SGH; 2011. p. 35-48.

15. GUS, Sytuacja demograficzna osób starszych i konsekwencje starzenia się ludności Polski w świetle prognozy na lata 2014-2050. Warszawa; 2014 (in Polish).

16. Oleński J. Rocznik demograficzny. Warszawa: Zakład Wydawnictw Statystycznych; 2009 (in Polish).

17. Pabiś M, Babik A. Najczęstsze problemy osób w wieku podeszłym na podstawie analizy zespołów geriatrycznych. Med Rodz 2007; 10(3): 62-69.

18. Wieczorkowska-Tobis K. Aging and disability. Gerontol Pol 2014; 3(2): 156-160.

19. Ślusarska B, Nowicki GJ, Bartoszek A, Wittwer S, Zboina B, Naylor K. Health problems of the elderly aged 6575 years survised by a community nurse. Gerontol Pol 2016; 24(2): 17-25.

20. Lecznar-Ligusz M. Nrurobiological mechanisms of age-related cognitive decline. Gerontol Pol 2014; 3(1): 166-171. 
21. Arczewska B, Bus I, Podgórski G., editors. Poradnik dla opiekunów osób dotkniętych chorobą Alzheimera. Łodź: Fundacja Miłorząb; 2014 (in Polish).

22. Leszek J. editor Choroby otępienne. Wrocław: Wyd. Continuo; 2011 (in Polish).

23. Beekes M, Thomzig A, Schulz WJ. Is there a risk of prion-like disease transmission by Alzheimer or Parkinsonassociated protein particles? Acta Neuropathol 2014; 128(3): 463-476. https://doi.org/10.1007/s00401-014-1324-9

24. Costa AS, Reich A, Fimm B . Evidence of the sensitivity of the MoCA alternate forms in monitoring cognitive change in early Alzheimer's disease. Dement Geriatr Cogn Disord 2014; 37(2): 95-103. https://doi.org/10.1159/000351864

25. Dobryszycka W, Leszek J. Aspekty diagnostyczne i terapeutyczne neurozwyrodnienia w chorobie Alzheimera, otępieniu, starzeniu. Wrocław: Continuo; 2007 (in Polish).

26. Jankiewicz A., editor. Poradnik dla opiekunów osób dotkniętych chorobą Alzheimera. Poznań: Wielkopolskie Stowarzyszenie Alzheimerowskie; 2008 (in Polish).

27. Kerr J, Rosenberg D, Frank L. The Role of the Built Environment in Healthy Aging: Community Design, Physical Activity, and Health among Older Adults. J Plan Literat 2012; 27(2): 43-60. https://doi.org/10.1177/0885412211415283

28. Chodorowski Z. Geriatria: postępy w diagnostyce i terapii. Gdynia: Grafica; 2007 (in Polish).

29. Golka M. Bariery w komunikowaniu i społeczeństwo (dez)informacyjne. Warszawa; PWN; 2000 (in Polish).

30. Talarska D, Wieczorkowski-Tobis K, Szwałkiewicz E., editors. Opieka nad osobami przewlekle chorymi w wieku podeszłym i niesamodzielnym. Podręcznik dla opiekunów medycznych. Warszawa: PZWL; 2010 (in Polish). 